\title{
Hypersegmented Neutrophils in Methotrexate Toxicity
}

\author{
Yuji Okazaki ${ }^{1}$, Takashi Watabu ${ }^{2}$, Koji Endo ${ }^{3}$ and Hiroshi Oiwa ${ }^{4}$
}

Key words: hypersegmented neutrophils, methotrexate toxicity, rheumatoid arthritis, folate deficiency

\author{
(Intern Med 57: 1055-1056, 2018) \\ (DOI: 10.2169/internalmedicine.9684-17)
}

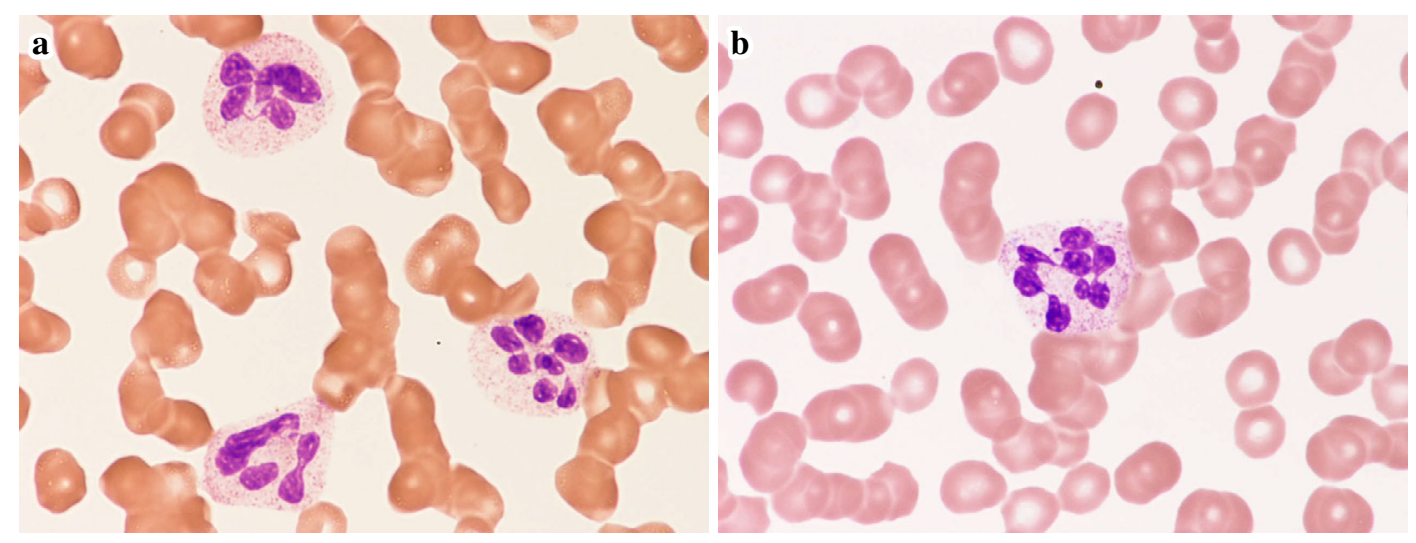

Picture.

An 87-year-old man was referred to the emergency room for a fever and sore throat. He had taken methotrexate (12 $\mathrm{mg} /$ week) for 2 years for rheumatoid arthritis and had last taken the drug 2 days before the presentation. A physical examination found multiple oral erosions. Laboratory tests showed a white blood cell (WBC) of $1,800 / \mu \mathrm{L}$ (neutrophils $72.8 \%$, lymphocytes $23.9 \%$, monocytes $1.1 \%$, eosinophils $0 \%$ ); hemoglobin, $11.6 \mathrm{~g} / \mathrm{dL}$; platelet count, $10,000 / \mu \mathrm{L}$; mean corpuscular volume (MCV), $89 \mathrm{fL}$; aspartate aminotransferase, $48 \mathrm{IU} / \mathrm{L}$; alanine aminotransferase, $24 \mathrm{IU} /$ $\mathrm{L}$; and C-reactive protein, $22.1 \mathrm{mg} / \mathrm{dL}$, while a complete blood cell count $(\mathrm{CBC})$ performed 11 days earlier had shown a WBC of 3,500/ $\mathrm{LL}$; hemoglobin, $13.4 \mathrm{~g} / \mathrm{dL}$; and platelet count, $135,000 / \mu \mathrm{L}$. Further work-up did not suggest an infectious cause, with negative results on blood cultures and a rapid influenza diagnostic test. A blood smear examination showed that hypersegmented neutrophils (with $\geqq 6$ lobes) comprised $35 \%$ of the total neutrophil population (Picture). Measurement of the serum level of folic acid and homocysteine was not possible on weekends and nonworking days; however, the patient was considered to have methotrexate toxicity, because hypersegmentation of the neutrophils indicated folate deficiency (1). His symptoms improved within a few days after the initiation of leucovorin treatment, and hypersegmented neutrophils also disappeared 7 days later, when a $\mathrm{CBC}$ showed a $\mathrm{WBC}$ of $1,700 / \mu \mathrm{L}$; hemoglobin, $8.8 \mathrm{~g} / \mathrm{dL}$; and platelet count, 36,000/ $\mu \mathrm{L}$. Seventeen days after admission, further improvement was observed: WBC, 8,800/ $\mu \mathrm{L}$; hemoglobin, $9.1 \mathrm{~g} / \mathrm{dL}$; and platelet count, 240,000/ $\mu$ L. Subsequently, his serum vitamin B12 concentration was within the normal range, and the high level of serum ferritin suggested that underlying the chronic inflammation had caused a normal value of MCV, despite the presence of a folate deficiency. Identification of hypersegmented neutrophils may be a simple and useful test for the diagnosis of methotrexate toxicity, even in emergency medicine.

The authors state that they have no Conflict of Interest (COI).

\section{Reference}

1. Bills T, Spatz L. Neutrophilic hypersegmentation as an indicator of incipient folic acid deficiency. Am J Clin Pathol 68: 263-267,

\footnotetext{
${ }^{1}$ Department of Internal Medicine, Akiota Hospital, Japan, ${ }^{2}$ Laboratory, Miyoshi Central Hospital, Japan, ${ }^{3}$ Department of General Internal Medicine, Tottori Prefectural Central Hospital, Japan and ${ }^{4}$ Department of Rheumatology, Hiroshima City Hiroshima Citizens Hospital, Japan Received: June 20, 2017; Accepted: August 7, 2017; Advance Publication by J-STAGE: December 21, 2017 Correspondence to Dr. Yuji Okazaki, m08026yo@jichi.ac.jp
} 
1977.

The Internal Medicine is an Open Access article distributed under the Creative
Commons Attribution-NonCommercial-NoDerivatives 4.0 International License. To view the details of this license, please visit (https://creativecommons.org/licenses/ by-nc-nd/4.0/).

(C) 2018 The Japanese Society of Internal Medicine Intern Med 57: 1055-1056, 2018 